\title{
PROBLEMATIKA IMPLEMENTASI QOWAID AL-LUGHAH DALAM MEMBACA KITAB KUNING DI MADRASAH TA'HILIYAH IBRAHIMY
}

\author{
Oleh: \\ Almannah Wassalwa \& Aisyatul Hanun \\ Fakultas Tarbiyah IAI Ibrahimy Situbondo \\ salwaelmanna90@gmail.com dan aisyah_alfaqieroh@yahoo.com
}

\begin{abstract}
:
Qowaid al-lughah is a science that much needed in learning Tutoring Reading Kitab, appropriate with real condition of failure learning to read kitab it resulted by any matter. There are, the teacher emphasize to attention of Qowaid al-Lughah for memorizing nadzam and material being studied. Qowaid al-Lughah function as a tool to read Kitab with correct harokat which less attention. So, we need for adjustments between ability of Qowaid al-Lughah with assembling reading skill of students. Authority students of Qowaid al-Lughah (Nahwu-Sharraf) does not necessarily ensure students are able to read kitab classics.
\end{abstract}

Key Words: Problematika, Qowa'id al-Lughah, Membaca Kitab Kuning

\section{A. Pendahuluan}

Bahasa Arab identik dengan bahasa Umat Islam. Banyak asumsi masyarakat yang berkembang bahwa bahasa Arab adalah bahasa umat Islam. Bahasa Arab juga diklaim sebagai "Bahasa Tuhan" (mengandung unsure keIlahian) karena al-Qur'an merupakan Kalam Tuhan, berupa Bahasa Arab yang terbukukan. Penghadiran Bahasa Arab tersebut kemudian mengalami proses sejarah. ${ }^{1}$ Diantara pendapat mengenai asal mula lahirnya Bahasa Arab, yaitu Bahasa Arab ada sejak zaman Nabi Adam, sehingga perintis tulisan Arab pola kalimat bahasa Arab adalah Adam. Pendapat ini merupakan pendapat yang paling klasik dan merupakan interpretasi secara langsung dari firman Allah:

وعلم ءادم الأسماء كلها ثم عرضهم على الملائكة فقال أنبئوني بأسماء هاؤلاء إن كنتم صدقين (البقرة : 31) "Dan Dia mengajarkan kepada Adam nama-nama (benda-benda) seluruhnya, kemudian mengemukakannya kepada para Malaikat lalu berfirman: " sebutkanlah kepada-Ku nama benda-benda itu jika kamu

1 Fathul Mujib, Rekonstruksi Pendidikan Bahasa Arab (Yogyakarta: Pedagogia, 2010), hlm. 34 . 
memang benar orang-orang benar".

Membaca berarti menelaah, keduanya sama-sama berbasis bacaan. Akan tetapi keduanya memiliki perbedaan yaitu Qiroah diartikan sebagai membaca, sedangkan menelaah lebih menekankan pada aspek analisis dan pemahaman pada bacaan. ${ }^{2}$ Dalam pembelajaran Bahasa Arab dikenal ada empat keterampilan berbahasa yang harus dimiliki siswa, yaitu keterampilan mendengar, keterampilan berbicara, keterampilan membaca, keterampilan menulis. Membaca (Maharatul Qiro'ah) memiliki keterampilan tersendiri. dimana keterampilan ini merupakan hal yang sangat urgen dalam memahami teks berbahasa arab, terutama pada kutub al-turats (kitab klasik). Memahami kitab klasik bukan sekedar membacakemudian menghafl, namun lebih kepada menganalisa dan menyerap makna yang terkandung dalam teks kitab tersebut.

Kutub al-Turats adalah salah satu warisan salafuna al-shalih yang patut dilestarikan. Di Indonesia kitab-kitab klasik masih sangat terjaga kelestariaannya. Hal ini didukung dan dibuktikan dengan berkembangnya pendidikan pesantren Indonesia. Kutub al-Turats tetap menjadi pedoman dalam istinbath hukum Islam.

Berdasarkan beberapa Hasil pengamatan, kondisi riil kegagalan pembelajaran membaca kitab secara umum adalah diakibatkan oleh beberapa hal. Diantaranya, adalah guru mentikberatkan perhatian pada Qowaid al-Lughah untuk menghafal nadzam ${ }^{3}$ serta materi yang dipelajari. Fungsi Qowai al-Lughah sebagai alat untuk membaca kitab dengan harokat yang benar kurang diperhatikan. Hal ini juga menimbulkan kesan bahwa pelajaran Qowaid al-Lughah ini terkesan parsial dan terpisah-pisah. Materi Qowaid al-Lughah terlihat tidak seiring dengan implementasinya terhadap maharoh al-Qiroah siswa. Melihat kemampuan siswa terhadap penguasaan Qowaid al-Lughah yang dapat dinilai cukup perlu adanya pengimbangan terhadap kemampuannya membaca kitab sebagai tujuan utama.

Untuk itu, perlu adanya penyesuaian antara kemampuan Qowaid alLughah siswa dengan penerapannyadalam kemampuan membaca. Penguasaan siswa terhadap Qowaid al-Lughah (Nahwu-Sharraf) belum tentu menjamin siswa mampu membaca kitab-kitab klasik. Tentu ada satu

2 Syaiful Mustofa,, Strategi Pembelajaran Bahasa Arab Inovatif, (Malang: UIN Press,2011), hlm. 161.

3 Biasanya, untuk memperoleh pemahaman tentang Qowaid al-Lughah guru mewajibkan siswa menghafal bait-bait teks dalam kitab Nahwu Shorrof. Seperti alJurumiyah, Imrithy, alfiyah dan lain-lain. Sedangkan pada praktik membaca kitab tanpa harakat, guru kurang memperhatikan keseimbangannya dengan materi Qowaid alLughah yang diperoleh. 
faktor tertentu atau lebih yang mendukung. Faktor ini lah yang perlu ditemukan kemudian untuk ditemukan akar permasalahannya dan soluinya.

Dari uraian latar belakang tersebut, peneliti merasa perlu adanya penelitian yang dilaksanakan untuk menemukan solusi yang kemudian disusun dalam bentuk laporan penelitian dengan judul " Problematika Implementasi Qowaid al-Lughah dalam membaca kitab kuning di Madrasah Ta'hiliyah Ibrahimy Putri Sukorejo".

\section{B. Metode}

Untuk mengetahui problematika yang terjadi di Madrasah Ta'hiliyah Ibrahimy, dengan memperhatikan unsur-unsur pokok pada rumusan masalah, tujuan, dan manfaat penelitian, maka pendekatan yang diperlukan dalam penelitian ini adalah pendekatan kualitatif dengan jenis penelitian studi kasus. Mengacu pada pernyataan Bogdan dan Biklen (1982) yang dikutip oleh Ainin, Studi kasus merupakan suatu rancangan penelitian yang memfokuskan pada satuan unit, seorang anak, suatu kelompok kecil, suatu sekolah atau kelas, suatu komunitas tertentu, dan suatu peristiwa. ${ }^{4}$

Pendekatan kualitatif, menurut Sugiyono, adalah metode penelitian yang digunakan untuk meneliti pada kondisi obyek yang alamiah (sebagai lawannya adalah eksperimen), dimana peneliti adalah sebagai instrument kunci, teknik pengumpulan data dilakukan secara triangulasi (gabungan), analisis data bersifat induktif, dan hasil penelitian kualitatif lebih menekankan pada makna daripada generalisasi. ${ }^{5}$

\section{Objek Penelitian}

Objek penelitian dalam penelitian kualitatif yang diobservasi menurut Spradley dinamakan situasi social, yang terdiri atas tiga komponen yaitu Place (tempat), Actor (pelaku), dan activities (aktifitas). ${ }^{6}$

Dalam penelitian ini peneliti menentukan pola sebagaimana pola diatas. Karena pengamatan yang dilakukan adalah situasi social dalam bidang pendidikan, Place yang berupa lingkungan Madrasah Ta'hiliyah Ibrahimy, Actor yang berupa siswa Madrasah Ta'hiliyah Ibrahimy, dan Activity berupa pembelajaran kitab kuning dan nahwu-sharraf di Madrasah Ta'hiliyah Ibrahimy.

${ }^{4}$ Moh. Ainin, Metodologi Penelitian Bahasa, (Surabaya: Hilal), hlm. 72.

${ }^{5}$ Sugiyono, Memahami Penelitian Kualitatif, Alfabeta (Bandung: 2012), hlm. 1.

${ }^{6}$ Sugiyono, Memahami Penelitian Kualitatif, hlm. 68. 
Kesimpulan yang hendak dicapai dalam penelitian ini adalah problematika pembelajaran kitab kuning di Madrasah Ta'hiliyah Ibrahimy serta solusi yang hendak dicapai.

\section{Hasil dan Pembahasan}

1. Kajian tentang Qowaid al-Lughah ('ilm al-Nahwu al-Shorof)

Bahasa Arab memiliki tiga unsure. Yaitu: (1) al-Aswat (2) alMufrodat (3) al-Tarakib. Salah satu unsur yang paling penting dalam Bahasa Arab adalah al-Tarakib. Al-Tarakib ini terdiri dari al-Qowaid alNahw dan Qowaid al-Shorf. Al-Tarakib menjadi kebutuhan pokok saat belajar Bahasa Arab. Seseorang tidak akan mungkin bisa membaca teks Arab dan membuat suatu kalimat tanpa memahami kaidah bahasa tersebut. $^{7}$

\section{a. Pengertian Qowaid al-Lughah}

Qowa'id secara bahasa merupakan bentuk Jama' dari kata Qo'idah yang berarti dasar atau aturan. Adapun secara terminology. Qowaid alLughah adalah kaidah-kaidah yang menjadi dasar penyusunan bahasa. Dalam Qowa'id al-Lughah terdapat dua ilmu penting yang sangat urgen untuk dipelajari yakni Nahwu dan Shorf.

Dalam Kitab Jami' al-Durus al-Arabiyyah, menjelaskan bahwa Ilmu Nahwu adalah ilmu asal-usul kalimat untuk mengetahui keadaan kalimat yang berbahasa Arab dari segi I'rob dan bentuknya. Artinya untuk mengetahui keadaan susunan kalimat. Dengan ilmu Nahwu, kita dapat mengetahui harakat yang tepat diakhir kalimat sesuai dengan keadaannya, rafa', nasab, jar dan jazm. ${ }^{8}$

\section{b. Metode Pembelajaran Qowaid al-Lughah}

Menurut Hasan Sayahatah ada tiga model pembelajaran al-Tarakib, model ini dikenal dengan metode Qiyasy (deduktif), metode istiqraiy (induktif) dan metode al-Mu'dilah (al-nash al-'araby). ${ }^{9}$

1) Metode Qiyasy (Deduktif). Metode Qiyasy adalah metode yang diadopsi dari metode terdahulu yang meliputi tiga langkah pengaplikasiannya yaitu guru mempermudah pembelajaran Qowa'id dengan menyebutkan Qa'idah-qa'idah atau ta'rif dari unsur yang umum lalu hlm. 91.

${ }^{7}$ Syaiful Mustofa, Strategi Pebelajaran Bahasa Arab, (Malang: UIN Press, 2010),

${ }^{8}$ Syaikh Musthafa al-Ghalayini, Jami' al-Durus al-Arabiyyah, (Beirut: Dar Al-Kutub al-Ilmiyah), hlm. 8

${ }^{9}$ Syaiful Mustofa, Strategi Pebelajaran Bahasa Arab, hlm. 97.

90 JURNAL LISAN AL-HAL 
unsur yang khusus dengan mendatangkan sebagian contoh-contoh yang kemudian dengan contoh itu siswa disuruh berlatih, untuk mengetahui sejauh mana pemahaman siswa. ${ }^{10}$

2) Metode Istiqraiy (Induktif). Metode Istiqraiy ini kebalikan dari metode Qiyasy. Metode ini mengajarkan dari hal-hal yang berbentuk juz'iyah ke bentuk yang lebih umum, maksudnya adalah pembelajaran tarakib mendatangkan contoh-contohnya terlebih dahulu kemudian diikuti dengan Qowa'id pada umumnya seperti yang ada di dalam kitab Nahwu al-Wadlifi, karena menurut metode ini pembelajaran Qowa'id kurang mendapatkan hasil yang maksimal kecuali dengan banyak memberikan latihan kepada siswa dari bab yang telah diberikan oleh guru. ${ }^{11}$

3) Metode al-Mu'dilah (al-nash al-'araby). Ini merupakan metode baru yang mrupakan pengembangan daripada dua metode sebelumnya. Oleh sebab itu disebut al-Mu'dilah karena metode pembelajaran nahwu yang bersambung tidak terpisah. Yang dimaksud dengan model bersambungdisini adalah potongan bacaan dari satu topik teks bacaan yang dibaca siswa, kemudian ditunjukkan beberapa jumlah dan beberapa hal yang dianggap spesifik kemudian setelah itu mengambil kesimpulan tentang kaidahnya dan yang terakhir ditambah dengan praktik yang berupa latihan. ${ }^{12}$

\section{c. Tujuan Pembelajaran Qowaid al-Lughah}

Pada tahap awal pembelajaran Ilmu al-Nahwu berorientasi pada upaya menumbuhkan kemampuan memahami umgkapan bahasa. Adapun tujuan pengajaran Qowaid al-Lughah adalah sebagai berikut: 1) Para pelajar mampu mengetahui fungsi kata-kata dalam kalimat dan memahami pengertian keseluruhan kalimat secara tepat dan cepat, dan 2) Mampu menyusun kalimat yang benar secara gramatika dan menggunakan bahasa lisan maupun tulisan untuk mengutarakan pikiran. Adapun tujuan pembelajaran sharaf adalah: 1) Untuk mengetahui seluk beluk kata, serta pengaruh perubahan bentuk kata terhadap fungsi dan arti kata, dan 2) Mampu memahami arti kata dalam setiap perubahan bentuknya secara pasti dan benar, serta mampu membuat bentuk-bentuk kata dengan benar dalam menggunakan bahasa Arab secara lisan maupun

10 Ibid., hlm. 98.

11 Ibid., hlm. 99.

12 Syaiful Mustofa, Strategi Pembelajaran Bahasa Arab, 102 
tertulis. ${ }^{13}$

\section{Kajian tentang Maharah al-Qiro'ah}

\section{a. Pengertian Maharah al-Qiro'ah dan Jenisnya}

Membaca adalah salah satu keterampilan berbahasa yang tidak mudah dan sederhana. Tidak sekedar membunyikan huruf dan kata. Akan tetapi melibatkan berbagai kerja akal dan pikiran. Membaca merupakan kegiatan yang meliputi semua bentuk-bentuk berfikir, memberi penilaian, memberi keputusan, menganalisis dan mencari pemecahan masalah. ${ }^{14}$

Membaca merupakan materi terpenting diantara materi-materi pembelajaran. Keterampilan membaca adalah kemampuan mengenali dan memahami isi sesuatu yang tertulis (lambang-lambang tertulis) dengan melafalkan atau mencernanya didalam hati. Membaca hakikatnya adalah proses komunikasi antara pembaca dengan penulis melalui teks yang ditulisnya, maka secara langsung di dalamnya ada hubungan kognitif antara bahasa lisan dengan bahasa tulis. ${ }^{15}$

Membaca pun merupakan suatu proses yang dilakukan serta dipergunakan oleh pembaca untuk memperoleh pesan, yang hendak disampaikan oleh penulis melalui media kata-kata/bahasa tulis.

Membaca dalam bahasa Arab secara sederhana dapat dibedakan ke dalam dua pengertian atau konsep yaitu: Lafz al-Maqru' dan Fahm alMaqru'. Lafz al-Maqru' berarti melafalkan symbol (tulisan) yang dibaca sesuai dengan kaidah-kaidah yang berlaku. Dimensi ini bersifat mekanik. sedangkan Fahm al-Maqru' berarti memahami apa yang dibaca. Dimensi ini mencakup aktivitas akal yang lebih kompleks, seperti memahami makna, melakukan interpretasi, menangkap ide penulis dan memberikan penilaian terhadapnya serta menghubungkannya dengan pengalamanpengalaman pembaca sehingga dapat diambil manfaat dari aktivitas membaca itu. ${ }^{16}$ Prof. DR Henry Guntur Tarigan juga menjelaskan bahwa secara garis besar terdapat dua aspek penting dalam membaca, yaitu:

Pertama, Keterampilan yang bersifat mekanis (Mechanical skills),

${ }^{13}$ Arkom Malibary, Pengajaran Bahasa Arab di Madrasah Aliyah, (Jakarta: Bulan Bintang, 1987), 19

${ }_{14}$ Bisri Mustofa, Metode dan Strategi Pembelajaran Bahasa Arab, (Malang: UIN Press,2010), 99

${ }^{15}$ Hermawan, Acep. Metodologi Pembelajaran Bahasa Arab, Bandung: Remaja Rosdakarya, 2011, hlm 143

${ }^{16}$ M Hariplish, Pengembangan Keterampilan Membaca dalam Bahasa Arab. (Jurnal Tarbawiyah Vol. 3 diterbitkan oleh Sekolah Tinggi Agama Islam Negeri Juarai Siswo Metro, 2006), hlm. 49-50.

$92 \mid$ JURNAL LISAN AL-HAL 
sering disebut sebagai keterampilan membaca nyaring yang dapat dianggap berada pada urutan yang lebih rendah (lower order). Aspek ini mencakup: 1) Pengenalan bentuk huruf, 2) Pengenalan unsur-unsur linguistik (kata, frase, pola klausa, kalimat, dan lainnya), 3) Pengenalan hubungan/korespondensi pola ejaan dan bunyi (kemampuan menyuarakan bahan tertulis atau "to bark at print"), dan 4) Kecepatan membaca bertaraf lambat. ${ }^{17}$

Kedua, Keterampilan yang bersifat pemahaman (Comprehension skills), sering disebut sebagai keterampilan membaca dalam hati atau diam yang dapat dianggap berada pada urutan yang lebih tinggi (higher order). Aspek ini mencakup: 1) Memahami pengertian sederhana (leksikal, gramatikal, retorikal), 2) Memahami signifikansi atau makna (maksud dan tujuan pengarang relevansi/keadaan kebudayaan, reaksi pembaca), 3) Evaluasi atau penilaian (isi, bentuk), dan 4) Kecepatan membaca yang fleksibel, yang mudah disesuaikan dengan keadaan. ${ }^{18}$

Dalam kegiatan membaca dalam hati, perlu diciptakan suasana kelas yang tertib sehingga memungkinkan siswa berkonsentrasi kepada bacaan. Secara fisik membaca dalam hati harus menghindari: 1) Vokalisasi, baik menggerakkan bibir sekalipun, 2) Pengulangan membaca, yaitu mengulangi gerak mata kepada kalimat sebelumnya yang sudah dibaca, 3) Menggunakan telunjuk atau gerakan kepala. ${ }^{19}$

\section{b. Tujuan Pembelajaran Membaca}

Ada beberapa tujuan yang hendak dicapai dalam pembelajaran membaca, Farida Rahim menjelaskan bahwa ada sembilan tujuan pembelajaran membaca, yaitu:201) Kesenangan, 2) Menyempurnakan membaca nyaring, 3)Menggunakan strategi tertentu, 4) Memperbaharui pengetahuannya tentang suatu topik, 5) Mengaitkan informasi baru dengan informasi yang telah diketahui, 6) Memperoleh informasi untuk laporan lisan atau tertulis, 6) Mengonfirmasikan atau menolak prediksi, 7) Menampilkan suatu eksperimen atau mengaplikasikan informasi yang telah diperoleh dari suatu teks dalam beberapa cara lain dan mempelajari tentang struktur teks, dan 8) Menjawab pertanyaan-pertanyaan yang

11.

${ }^{17}$ Henry Guntur Tarigan, Membaca: Sebagai Suatu Keterampilan Berbahasa, hlm.

${ }^{18}$ Henry Guntur Tarigan, Membaca: Sebagai Suatu Keterampilan Berbahasa, hlm. 12.

${ }^{19}$ Ahmad Fuad Effendy, Metodologi Pengajaran Bahasa Arab, hlm. 170.

${ }^{20}$ Farida Rahim, Pengajaran Membaca di Sekolah Dasar (Jakarta: PT Bumi Aksara,2005), hlm. 11 
spesifik.

\section{c. Kriteria Pemilihan Bahan Pembelajaran Membaca}

Untuk mencapai hasil yang memuaskan dalam penyajian pembelajaran membaca, guru sebaiknya memperhatikan hal-hal berikut:

1. Sesuai atau dapat menunjang tercapainya tujuan pembelajaran.

2. Sesuai dengan tingkat pendidikan dan perkembangan siswa pada umumnya.

3. Terorganisasi secara sistematik dan berkesinambungan.

4. Mencakup hal-hal yang bersifat faktual maupun konseptual.

\section{d. Media dan Strategi Pembelajaran Membaca}

Media pembelajaran pada dasarnya merupakan alat bantu yang dapat mempermudah pembelajaran. Dalam pembelajaran membaca, media pembelajaran dapat berupa teks bacaan. Fungsi media tersebut adalah untuk memperjelas pemahaman siswa dalam memahami informasi yang dibaca, maka fungsi media dalam pembelajaran membaca sangatlah penting. Dengan menggunakan media siswa akan tertarik dan mudah dalam memahami informasi. Berkaitan dengan penjelasan di atas, berikut dikemukakan beberapa prinsip yang dapat digunakan untuk memilih dan menentukan media pembelajaran membaca. Menurut Sumadi mengatakan prinsip untuk menentukan media dalam bahasa adalah sebagai berikut:

Pertama, Fungsional ,artinya cocok dengan tujuan pembelajaran yang dilakukan dan benar-benar menunjang ketercapaian tersebut. Kedua, Tersedia, artinya media yang akan digunakan ada dan sudah disiapkan. Ketiga, Murah, artinya media yang digunakan tidak harus mahal tetapi terjangkau dan sesuai dengan kemampuan yang dimiliki. Keempat, Menarik, artinya media yang digunakan adalah media menarik dan sesuai dengan kebutuhan siswa. Setidaknya ada beberapa kriteria untuk menentukan media yang menarik bagi siswa yaitu: a) sesuai dengan kebutuhan siswa, b) sesuai dengan dunia siswa, c) baru, dan d) menantang. Pada dasarnya pembelajaran membaca disampaikan dengan menggunakan media berupa teks ataupun bacaan.

Adapun strategi pembelajaran membaca yang dapat digunakan antara lain adalah:

1) Strategi pembelajaran membaca nyaring

Strategi ini bertujuan agar siswa mampu melatih kemampuannya dalam mengenali bentuk bunyi dan huruf bahasa Arab, ketepatan intonasi ataupun irama dan kelancaran dalam membaca. Langkah-langkah yang

94 JURNAL LISAN AL-HAL 
bisa digunakan adalah:

a) Guru memulai pelajaran dengan memberikan contoh qira'ah jahriyah dengan benar. Guru dimungkinkan membacakan teks dan diikuti oleh siswa dengan melihat teks. Siswa menirukan bacaan guru.

b) Sebaiknya teks yang disajikan pendek serta mudah dipahami siswa, sehingga fokus hanya untuk mengucapkan dan tidak pindah untuk berfikir tentang makna.

c) Tersedianya waktu yang cukup untuk melatih siswa mendengarkan teks, setelah selesai kemudian mereka diminta untuk membaca teks dengan keras.

d) Melatih siswa membaca dengan cara bersama-sama dan juga individu. Saat siswa membaca secara individu guru harus aktif untuk mendorong siswanya membaca dengan cepat tidak membaca kata perkata atau sering berhenti dalam setiap baris.

e) Guru mencatat kesalahan-kesalahan yang terjadi baik berkaitan dengan bunyi maupun pengucapan. Berdasarkan catatan tersebut guru bisa mencari penyebab kesalahan dan mencari solusinya. ${ }^{21}$

2) Strategi pembelajaran membaca dalam hati

Strategi ini bertujuan agar siswa mampu melatih kemampuannya dalam memahami isi maupun makna yang terkandung di dalam teks bacaan. Langkah-langkah metode qowaid wa tarjamah yang bisa digunakan dalam pembelajaran membaca dalam hati adalah: a) Guru memulai pelajaran dengan membacakan teks, b) Kemudian guru menterjemahkan teks kebahasa siswa, c) Pelajaran dilanjutkan dengan penjelasan dari guru, dan d) Di akhir pelajaran siswa mengulang bacaan yang telah dipelajari. ${ }^{22}$

\section{e. Evaluasi Pembelajaran Membaca}

Pada dasarnya evaluasi bertujuan untuk mengetahui atau mengukur hasil yang dicapai siswa dalam proses pembelajaran. Oleh karena itu, evaluasi harus sesuai dengan tujuan apa yang ingin dicapai dalam pembelajaran, dalam hal ini adalah standar kompetensi. Standar kompetensi yang diujikan dalam tes membaca adalah kemampuan seseorang untuk menangkap pesan tertulis dengan benar, cepat dan cermat.

Disamping bunyi, siswa juga dihadapkan pada unsur bahasa

${ }^{21}$ Abd. Wahab Rosyidi dan Mamlu'atul Ni'mah, Memahami Konsep Dasar Pembelajaran Bahasa Arab (Malang: UIN-Maliki Press, 2012), hlm. 73.

22 Ibid, 73. 
lainnya, misalnya kosa kata dan qowa'id (tata bahasa). Karena itu kompetensi atas unsur dan ketrampilan bahasa memiliki karakteristik sendiri-sendiri, namun sebagaimana dalam tes berbicara sesungguhnya dalam satu kompetensi yang diujikan terkadang juga melibatkan kompetensi bahasa yang lain.

\section{f. Metode Pembelajaran Membaca Kitab Kuning}

Adapun beberapa metode yang sejauh ini banyak digunakan dan sesuai dengan tujuan pembelajaran qowa'id al-Lughah, antara lain:

1) Metode Qowa'id wa al-Tarjamah

Metode ini sering dijuluki dengan metode tradisional. Sepintas julukan ini mengandung kesan "metode kolot". Boleh jadi demikian, sebab metode ini memang sudah tua. Asumsi yang mendasari metode Qowa'id wa al-Tarjamah adalah suatu logika semesta yang mengatakan bahwa semua bahasa didunia dasarnya sama, dan tata bahasa adalah cabang dari logika. ${ }^{23}$

Metode Qowa'id wa al-Tarjamah melihat bahasa secara preskriptif, dengan demikian kebenaran bahasa berpedoman pada petunjuk tertulis, yaitu aturan-aturan gramatikal yang ditulis oleh ahli bahasa, bahkan menurut ukuran guru.

Dasar pokok metode ini adalah hafalan kaidah, analisa gramatika terhadap wacana, lalu terjemahnya kedalam bahasa yang digunakan sebagai pengantar pelajaran. ${ }^{24}$ Sedangkan perhatian terhadap kemampuan berbicara sangat kecil. Ini berarti bahwa titik tekan metode ini bukan melatih para pelajar agar pandai berkomunikasi secara aktif, melainkan memahami bahasa secara logis yang didasarkan kepada analisa cermat terhadap aspek kaidah tata bahasa. Menurut al-Naqah, tujuan metode ini adalah agar para pelajar pandai dalam menghafal dan memahami tata bahasa, mengungkapkan ide-ide dengan menerjemahkan bahasa ibu atau bahasa kedua ke dalam bahasa asing yang dipelajari, dan membekali mereka agar mampu memahami teks bahasa asing dengan menerjemahkannya ke dalam bahasa sehari-hari atau sebaliknya. ${ }^{25}$

2) Metode Qiro'ah

23 Sri Utari Subyakto Nababan, Metodologi Pengajaran Bahasa, (jakarta: Gramedia Pustaka Utama, 1993), hlm. 11.

${ }^{24}$ Ramzi Munir Ba'labaki, Mu'jam al-Musthalahat al-Lughawiyah, (Bairut: Dar alIlm li al-Malayin, 1990), hlm. 216.

25 Acep Hermawan, Metodologi Pembelajaran Bahasa Arab, (Bandung: PT Remaja Rosdakarya, 2011), hlm. 71.

96 JURNAL LISAN AL-HAL 
Membaca dalam metode ini yang sangat menekankan keterampilan membaca diam (al-Qiro'ah al-Shamithah) untuk meningkatkan pemahaman, dengan sesekali juga memandang penting membaca nyaring karena untuk melatih kemampuan pengucapan yang benarmerupakan kegiatan yang banyak dilatihkan. Metode ini juga menerapkan diskusi baik antar kelompok maupun perorangan. Di Pondok Pesantren Salafiyah Syafi'iyah metode ini banyak diterapkan di Ma'had Aly sebagai pusat kajian kitab kuning bidang Fiqh-Ushul Fiqh.

3) Metode Amtsilati

Metode ini pertama kali digagas oleh KH. Taufiqul Hakim di Jepara. Metode ini adalah metode cepat membaca kitab kuning secara sistematis yang disempurnakan dengan Nadzam-nadzam alfiyah ibn al-Malik. ${ }^{26}$

\section{E. Profil Madrasah Ta'hiliyah Ibrahimy Salafiyah Syafi'iyah}

Fungsi utama dan pertama Pondok Pesantren adalah merupakan lembaga pendidikan. Sebagai manifestasi dan penegasan dari fungsi tersebut, Pondok Pesantren Salafiyah Syafi'iyah Sukorejo menyelenggarakan berbagai pendidikan agama dan umum baik formal maupun non formal. Dengan demikian, Pondok Pesantren mempunyai peranan sangat penting yang berhadapan langsung dengan masyarakat. Keberhasilan dan kegagalan pendidikan. Sangatlah ditentukan oleh kreatifitas dan dinamika dari pengelola pendidikan itu sendiri.

Dari pendidikan tersebut baik mulai dari MI sampai MA semuanya sama-sama saling mewujudkan visi dan misinya masing-masing dalam memajukan suatu lemabaga pendidikan yang berada dalam naungan pondok pesantren.

Untuk itu dalam mencetak insan-insan muslim yang berkualitas dari kalangan Masiswa sendiri timbullah suatu keinginan untuk berpenampilan diri, berwawasan keilmuan yang luas, profesional, berdisiplin tinggi dan selalu bersikap pro-aktif dalam menghadapi dan menyelesaikan suatu masalah.

Dalam proses belajar mengajar khususnya siswa MI yang rata-rata semua siswa-siswinya bercampur baur antara berbagai tingkatan yang dalam tahap memikirannya sangatlah jauh berbeda. Dari perbedaan inilah akhirnya Mahasiswa mewujudkan suatu wacana baru lembar pendidikan Pondok Pesantren untuk memisahkan diri dan mengadakan suatu

${ }^{26}$ Alfiyah Ibn al-Malik adalah kitab Nahwu yang disusun oleh Syeikh Jamaluddin Muhammad bin Abdullah bin Malik yang telah dipelajari di berbagai pesantren di seluruh dunia yang kemudian diisyarahkan oleh Syaikh Jalaluddin al-Suyuthi 
pengelompokan yang akhir disepakati oleh Pengurus Pesantren dan direkomendasi oleh Pengasuh

Fungsi utama dan pertama Pondok Pesantren adalah merupakan lembaga pendidikan. Sebagai manifestasi dan penegasan dari fungsi tersebut, Pondok Pesantren Salafiyah Syafi'iyah Sukorejo menyelenggarakan berbagai pendidikan agama dan umum baik formal maupun non formal. Dengan demikian, Pondok Pesantren mempunyai peranan sangat penting yang berhadapan langsung dengan masyarakat. Keberhasilan dan kegagalan pendidikan. Sangatlah ditentukan oleh kreatifitas dan dinamika dari pengelola pendidikan itu sendiri.

Dari pendidikan tersebut baik mulai dari MI sampai MA semuanya sama-sama saling mewujudkan visi dan misinya masing-masing dalam memajukan suatu lemabaga pendidikan yang berada dalam naungan pondok pesantren.

Untuk itu dalam mencetak insan-insan muslim yang berkualitas dari kalangan Masiswa sendiri timbullah suatu keinginan untuk berpenampilan diri, berwawasan keilmuan yang luas, profesional, berdisiplin tinggi dan selalu bersikap pro-aktif dalam menghadapi dan menyelesaikan suatu masalah.

\section{VISI dan MISI}

Untuk misinya dalah Terwujudnya mahasiswa yang beriman, berilmu, beramal, bertaqwa, berakhlak karimah, serta cerdas dan terampil, sebagai kader muslim khaira ummah. Sedangkan MISInya meliputi: a) Mengembangkan manajemen pendidikan yang transparan, akuntabel, partisipatif dan efektif, b) Menyelenggaran penguatan dan percepatan pembelajaran bahasa arab dan ilmu-ilmu agama berbasis kitab kuning secara teoritis dan praktis, aktif, kreatif, serta menyenangkan, c) Menciptakan suasana Madrasah yang dinamis, harmonis dan komunikatif, d) Membiasakan mahasiswa disiplin belajar, berfikir ilmiah dan bertanggung jawab, dan e) Menumbuhkembangkan budi luhur dan akhlak karimah $^{27}$

\section{Letak Geografis}

Madrasah Ta'hiliyah Ibrahimy terletak dalam kompleks Pondok Pesantren yang memiliki iklim religius yang cukup tinggi. Kompleks madrasah juga terletak dilingkungan yang cukup teratur dengan lokasi gedung yang dibagi sesuai kondisi siswi yang stiap tahunnya hampir dapat

27 Data Profil MTI Salafiyah Syafi'iyah Sukorejo

98 JURNAL LISAN AL-HAL 
dipastikan bertambah. Karena Pesantren Salafiyah Syafi'iyah Sukorejo telah memiliki kompleks tersendiri, maka madrasah tidak berbaur dengan perkampungan dan persawahan penduduk sekitar desa.

\section{F. Pembahasan Hasil Penelitian}

1. Kemampuan Qowa'id al-Lughah siswi Madrasah Ta'hiliyah Putri Salafiyah Syafi'iyah Sukorejo

Bimbingan membaca kitab seringkali menjadi momok bagi siswi madrasah. Tidak hanya di Madrasah Ta'hiliyah, di lembaga-lembaga lainnya dilingkungan Pondok Pesantren Salafiyah Syafiiyah Sukorejo semisal Madrasah Tsanawiyah dan Madrasah Aliyah juga menjadi momok. Selain kemampuan membaca al-Qur'an, kemampuan membaca kitab kuning menjadi salah satu kompetensi dasar yang wajib dimiliki oleh setiap siswi di Madrasah di Lingkungan Pondok Pesantren Salafiyah Syafi'iyah Sukorejo. Madrasah Ta'hiliyah Ibrahimy sebagai jenjang pendidikan non formal yang dalam pembelajaran Bimbingan Membaca Kitab menerapkan berbagai metode, dan tentu saja ini menyikapi perbedaan potensi siswi bukan hanya disetiap kelas melainkan setiap individu pula.

Qowa'id al-Lughah merupakan bagian pokok dalam pembelajaran Bahasa Arab khususnya dalam membaca kitab kuning. Sebelum melaksanakan pembelajaran tehnik membaca kitab, penting untuk terlebih dahulu memiliki alatnya. Yakni Qowa'id al-Lughah yang disebut sebagai ilmu alat.

Oleh karena itu Kepala Bidang Pendidikan Tinggi Pesantren Salafiyah Syafiiyah Sukorejo menetapkan dan menyesuaikan kurikulum disusun sesuai dengan tujuan dan target pembelajaran. Tehnik penyusunan terpadu ini memiliki kelebihan dan kelemahan tersendiri. Kelebihannya adalah menyatunya sistem dalam satu naungan Yayasan Pondok Pesantren Salafiyah Syafiiyah Sukorejo sehingga lembaga tidak perlu mengkonstruksi kurikulum sedemikian rupa. Namun kekurangannya sangat mempengaruhi dalam proses pembelajaran. Ini disebabkan oleh tim penyusun yang tidak seluruhnya memahami kondisi lapangan secara merata. Mseki dalam tim penyusunan kurikulum melibatkan beberapa guru, akan tetapi kondisi riil yang berbeda dalam satu yayasan tidak relevan dengan apa yang telah disepakati. Juga disebabkan oleh perbedaan kondisi kelas dan individu siswi di setiap Madrasah, akibatnya efektifitas pembelajaran di Madrasah kurang maksimal. 
Kemampuan siswi di Madrasah Ta'hiliyah Ibrahimy Putri masih dapat dinilai kurang dari target yang ingin dicapai. Hal ini dapat disimpulkan dari observasi dan wawancara yang dilakukan peneliti. Sejumlah siswi yang memilliki kemampuan membaca kitab yang baik lebih sedikit dari yang memiliki kemampuan menengah ke bawah.

Siswi dapat menghafal teori dan materi-materi yang telah diajarkan. Misalnya pembagian kalimat, serta pengertian dan pembagian i'rab. Akan tetapi setelah mencoba mengimplementasikannya terhadap kitab kuning (syarh matn al-Jurumiyah) masih banyak ditemukan kesalahan atau bacaan-bacaan yang tidak tepat. Itu dikarenakan mereka kurang dalam mempraktekkan bacaan kitab kuning pada waktu proses pembelajaran maupun diluar jam pembelajaran.

Selain itu, dapat dilihat juga bahwa secara menyeluruh siswi Madrasah Ta'hiliyah yang notabenenya mereka adalah mahasiswi baru dari Institut Agama Islam Ibrahimy. Untuk mengisi kekosongan waktu pada pagi hari maka mereka diwajibkan untuk mengikuti pembelajaran di Madrasah Ta'hiliyah. Banyak dari mereka yang belum mempunyai basic keilmuan Nahwu dan Sharf, sangat memungkinkan sekali jika dari mereka banyak yang belum mampu untuk membaca kitab kuning.

2. Problematika implementasi Qowa'id al-Lughah dalam praktek membaca kitab siswi Madrasah Ta'hiliyah Putri Salafiyah Syafi'iyah Sukorejo

Menurut Ustad Saniman, diantara problem-problem yang dihadapi saat berlangsungnya pembelajaran Qowa'id al-Lughah adalah:

a. Pola hubungan pendidik dan murid dalam pembelajaran BMK terkadang terlihat kaku seperti hubungan tuan dan majikan, guru hanya menyajikan contoh kalimat kemudian siswi dituntut dan diberi tugas membuat contoh serupa serta menentukan kedudukan kalimat. Guru jarang mengetahui kekuatan dan kelemahan siswa dalam pembelajarannya.

b. Pembelajaran Qowaid al-Lughah sering berorientasi untuk menjelaskan keadaan yang tidak memasuki wilayah substantif; menjelaskan keadaan rafa', nasab, mubtada', fa'il, maf'ul bih, na'ibul fa'il dengan mengabaikan implikasi makna yang menyertainya dan tidak memperhatikan konsekuensi makna yang ada dalam pola kalimat.

c. Pembelajaran Qowaid al-Lughah diajarkan secara parsial, terpisahpisah serta mengalami penyempitan makna dan pemahaman siswa karena hanya membatasi dengan memberikan contoh tanpa dikaji dengan kritis.

$100 \mid$ JURNAL LISAN AL-HAL 
d. Penjelasan pembelajaran Qowaid al-Lughah oleh pendidik hanya terpacu pada metode bacaan kitab dan memberikan contoh dengan satu kalimat saja tanpa siswi yang mempraktekkan diri untuk membaca.

e. Pendidik menitik beratkan pada Qowaid al-Lughah untuk menghafal dan memahami isi bacaan. Pengajaran gramatika sebatas hafalan syairsyair atau matan tentang ilmu Nahwu dan ilmu Sharf itu sendiri. Biasanya dalam bentuk lagu dan musik tertentu.

f. Pembelajaran Qowaid al-Lughah dan Belajar Membaca Kitab (BMK) dengan disiplin ilmu lain, seperti ilmu al-Qur'an atau ilmu bahasa (semiotika dan semantik), psikologi dan humaniora.

g. Selama proses pembelajaran BMK, pendidik hanya memfokuskan pada materi saja tanpa mengimbangi praktek membaca dengan intens terhadap siswi.

Pembelajaran Qowaid al-Lughah sangat jelas nampak dalam pengamatan WaKa. Kurikulum, bahwa terkesan parsial. Sehingga dalam penerapan membaca kitab dari satu topik ke topik lainnya kurang bersinergi.

Meski tanpa disadari oleh pendidik, ada batas yang terbentuk dari pola hubungan pendidik dan siswi. Bisa timbul dari salah satu keduanya, atau bahkan dari keduanya. Sikap guru terhadap siswi yang terlalu membatasi diri, atau bisa jadi siswi yang menjaga hubungan sebab terlalu khawatir terjadi su'ul adab. Hal ini perlu diperhatikan agar komunikasi antara pendidik dan siswi terjaga dengan baik sehingga proses pembelajaran dapat mencapai hasil yang optimal.

Salah satu problem yang memicu tersendatnya pemahaman siswi adalah buku ajar. Buku ajar atau buku pedoman Madrasah Ta'hiliyah Ibrahimy Putri Salafiyah Syafi'iyah tidak digunakan secara khusus pada materi BMK. Buku ajar digunakan pada materi Nahwu dan Sharf. Sedangkan BMK terdapat kurikulum tersendiri yang disusun oleh Kepala Bidang Pendidikan dan Pengajaran dan materi yang dirangkai secara otodidak oleh pendidik BMK. Maka dipandang perlu untuk menyusun buku ajar sebagai pedoman yang sesuai dengan kurikulum dan target pembelajaran.

Problem yang sejak beberapa tahun terjadi, sebagaimana yang diungkapkan oleh Ustad Heriyanto, siswi dengan sangat mudah melupakan materi yang pernah diajarkan pada tahun sebelumnya. Ini disebabkan karena mereka terlalu dituntut untuk banyak menghafal teori. Sedangkan tidak semua teori dalam satu susunan kurikulum pada satu tahun akan diterapkan sekaligus pada BMKdi tahun tersebut. Tahap-tahap

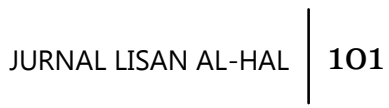


inilah yang kurang dipahami dan diperhatikan oleh pendidik. Sehingga kemampuan siswi setiap individu dalam satu kelas menjadi terabaikan. Problem ini belum menemukan titik pencerahan sampai saat penelitian ini dilaksanakan.

Selain itu, peneliti juga menemukan satu problem yang mungkin tidak pernah disadari dan diketahui oleh pendidik, yakni kemampuan siswi sangat minim dalam kemampuan Bahasa Arab, baik secara keseluruhan maupun individu. Kemampuan bahasa Arab siswi sangat bervariasi. Ada yang sebelumnya sudah mengenal bahasa Arab bahkan sudah mampu menentukan harakat terakhir kalimat. Sebaliknya, ada juga yang belum pernah belajar bahasa Arab atau hanya sekedar mengetahui beberapa kosakata dasar dalam bahasa Arab. Karena kitab kuning menggunakan bahasa Arab dan sangat erat sekali kaitannya dengan bahasa Arab. Sedangkan bahasa Arab tidak lepas dari ilmu Nahwu dan ilmu Sharf.

Problem tidak hanya terjadi pada siswi, akan tetapi juga dialami oleh pendidik yang memiliki kelemahan dalam membimbing siswi dalam membaca kitab. Misalnya, lebih banyak memikirkan orientasi berdasarkan materi dalam cakupan buku teks ajar (mengejar target terselesaikannya materi) dibanding memberi pengalaman yang dibutuhkan siswi. Biasanya hal semacam ini dikarenakan adanya tuntutan bagi pendidik agar nilai hasi ujian baik. Ini menyebabkan tujuan jangka panjang menjadi terlupakan sehingga pendidik dan siswi sama-sama cenderung mengejar target nilai sesuai kriteria ketuntasan minimal (KKM).

Dan salah satu kelemahan guru yaitu tidak dapat menjelaskan orientasi dan tujuan pembelajaran Qowaid al-Lughah atau bimbingan membaca kitab dengan baik. Sehingga tidak ada motivasi khusus bagi siswi dalam mempelajari Qowaid al-Lughah dan BMK. Orientasi pembelajaran sangat perlu dijelaskan kepada siswi untuk memicu motivasi belajar dan tujuan ilmu tersebut dipelajari menjadi nampak.

Problem yang terjadi tahun ke tahun adalah banyaknya jumlah siswi yang tak terbendung. Hingga pembelajaran tidak efektif dan tidak mencapai hasil yang optimal. Jumlah siswi yang terisi masing-masing kelas mencapai rata-rata 40 siswi. Hal ini mengurangi efisiensi proses pembelajaran, akhirnya situasi yang integratif-komunikatif menjadi sulit terbangun.

3. Solusi terhadap Problematika implementasi Qowa'id al-Lughah dalam praktek membaca kitab siswi Madrasah Ta'hiliyah Putri Salafiyah Syafi'iyah Sukorejo

$102 \mid$ JURNAL LISAN AL-HAL 
Dari beberapa problematika diatas peneliti juga mengidentifikasi solusi dari beberapa pendidik di Madrasah Ta'hiliyah Ibrahimy Putri Salafiyah Syafiiyah Sukorejo, diantaranya adalah:

a. Integritas guru terhadap siswi lebih diperhatikan agar memicu motivasi dan semangat siswi dalam belajar

b. Memberikan pelatihan terhadap pendidik Belajar Membaca Kitab sebagai bekal untuk menemukan metode-metode baru yang lebih inovatif dan menyenangkan

c. Penyesuaian kurikulum yakni dengan merekontruksi penyusunan kurikulum tematik sesuai dengan pokok pembahasan dalam Bimbingan Membaca Kitab agar tepat sasaran dan mencapai target.

d. Membekali dan memotivasi siswi dalam belajar Bahasa Arab, Qowaid al-Lughah dan Belajar Membaca Kitab serta keilmuan lainnya yang berkaitan agar dapat meningkatkan potensi kemampuan siswi.

\section{G. Simpulan}

Dari hasi penelitian dan analisa yang diperoleh dapat disimpulkan sebagai berikut: Pertama, Siswi Madrasah Ta'hiliyah Ibrahimy Putri Salafiyah Syafiiyah Sukorejo memiliki kemampuan yang cukup baik dalam Qowaid al-Lughah. hal ini dapat dilihat dari hasil evaluasi harian maupun semester yang memiliki nilai diatas KKM. Kedua, Problem yang terdapat pada implementasi Qowaid al-Lughah dalam membaca kitab diantaranya adalah: a) Kurangnya semangat membaca siswi, sehingga menjadikan lisan mereka kaku saat membaca kitab dan cenderung terjadi kekeliruan, b) Penguasaan siswi terhadap Qowaid al-lughah tidak menyeluruh dan mendalam. Sehingga jika alat yangg digunakan tidak lengkap maka terjadi ketidaksempurnaan dalam bacaan terlebih dalam pemahaman, c) Waktu, jam pembelajaran yang terlalu sedikit sehingga tidak menyempatkan siswi untuk praktek membaca dan penggunaan waktu lebih banyak digunakan untuk menyampaikan materi, d) Dasar keilmuan yang dimiliki siswi sebelum belajar di Madrasah pada Qowaid al-Lughah sangat minim, dan e) Pembelajaran BMK yang bersifat parsial, metode yang digunakan dengan menghafal teori sehingga ketika praktek membaca kitab sanagt lemah.

Solusi dalam mengatasi problem implementasi Qowaid al-Lughah dalam membaca kitab diantaranya adalah: a) Integritas guru terhadap siswi lebih diperhatikan agar memicu motivasi dan semangat siswi dalam belajar dan Memberikan pelatihan terhadap pendidik Belajar Membaca Kitab sebagai bekal untuk menemukan metode-metode baru yang lebih inovatif dan menyenangkan, dan b) Merekontruksi penyusunan kurikulum tematik sesuai dengan pokok pembahasan dalam Bimbingan Membaca 
Kitab agar tepat sasaran dan mencapai target. Dan Membekali dan memotivasi siswi dalam belajar Bahasa Arab.

\section{DAFTAR PUSTAKA}

Ainin,Moh. Metodologi Penelitian Bahasa. Surabaya: Hilal

Ba'labaki, Ramzi Munir. Mu'jam al-Musthalahat al-Lughawiyah. Bairut: Dar al-Ilm li al-Malayin.1990.

Effendy, Ahmad Fuad. Metodologi Pengajaran Bahasa Arab. Malang: Misykat, 2012.

Ghalayini (al), Syaikh Musthafa. Jami' al-Durus al-Arabiyyah. Beirut: Dar AlKutub al-Ilmiyah

Hariplish, M. Pengembangan Keterampilan Membaca dalam Bahasa Arab. Jurnal Tarbawiyah Vol. 3 diterbitkan oleh Sekolah Tinggi Agama Islam Negeri Juarai Siswo Metro, 2006.

Hermawan, Acep. Metodologi Pembelajaran Bahasa Arab, Bandung: Remaja Rosdakarya. 2011.

Malibary, Arkom. Pengajaran Bahasa Arab di Madrasah Aliyah, Jakarta: Bulan Bintang. 1987.

Marhamah. Hubungan Antara Pemahaman Bacaan dengan Keterampilan Menulis Bahasa Inggris. Jurnal Pendidikan Islam Vol. IX No. 2 Juli Fakultas Agama Islam Universitas Islam Jakarta. 2006.

Mujib, Fathul. Rekonstruksi Pendidikan Bahasa Arab. Yogyakarta: Pedagogia. 2010.

Mustofa, Syaiful. Strategi Pembelajaran Bahasa Arab Inovatif. Malang: UIN Press. 2011.

Mustofa, Bisri. Metode dan Strategi Pembelajaran Bahasa Arab. Malang: UIN Press. 2010.

Nababan, Sri Utari Subyakto. Metodologi Pengajaran Bahasa. Jakarta: Gramedia Pustaka Utama. 1993.

Rahim, Farida. Pengajaran Membaca di Sekolah Dasar. Jakarta: PT Bumi Aksara. 2005.

Rosyidi, Abd. Wahab dan Mamlu'atul Ni'mah. Memahami Konsep Dasar Pembelajaran Bahasa Arab. Malang: UIN-Maliki Press. 2012.

Sugiyono, Memahami Penelitian Kualitatif Alfabeta. Bandung. 2012.

Suharsaputra, Uhar. Metode Penelitian; Kuantitatif, kualitatif dan Tindakan. Bandung: Refika Aditama. 2012.

$104 \mid$ JURNAL LISAN AL-HAL 